\title{
PENGARUH PEMBERIAN EKSTRAK ETANOL UMBI BAWANG DAYAK (Eleuthrine Palmifolia $(L$. Merr) SECARA ORAL PADA MENCIT BALB/c TERHADAP PENCEGAHAN PENURUNAN JUMLAH NK SEL DAN $\mathrm{CD} \mathrm{8}^{+}$
}

\author{
Nelly Meiliana \\ Program Studi S2 Imunologi, Sekolah Pascasarjana Universitas Airlangga Surabaya \\ JL. Airlangga No. 4-6 Surabaya (60286) Telp. 031-5041566, Fax. (031) 5029856 \\ Email: nelly.meiliana@yahoo.co.id
}

\begin{abstract}
ABSTRAK
Penentuan kemampuan ekstrak etanol umbi bawang dayak (Eleutherine Palmifolia (L.) Merr) sebagai imunoprotektor dan imunomodulator terhadap mencit BALB/c melalui pengamatan jumlah sel pengekspresi $\mathrm{CD} 56^{+}$dan $\mathrm{CD} 8^{+}$dengan menggunakan metode Imunohistokimia. Analisis statistik dengan Anova satu arah dilanjutkan dengan uji Beda Nyata Terkecil (BNT) menunjukkan bahwa ekstrak etanol umbi Bawang Dayak menunjukkan hasil beda bermakna (signifikan) pada sel pengekspresi $\mathrm{CD} 8^{+}$sedangkan sel pengekspresi $\mathrm{CD} 56^{+}$menunjukkan hasil tidak berbeda (nonsignifikan). Hal ini berarti ekstrak etanol umbi Bawang Dayak berpotensi sebagai imunomodulator dan imunoprotektor pada sel sitotoksik $\left(\mathrm{CD} 8^{+}\right)$untuk imunitas seluler. Ekstrak etanol umbi Bawang Dayak berdasarkan jumlah rerata meningkat pada sel pengekspresi CD $56^{+}$, namun masih sangat rendah sehingga hasil uji tidak signifikan.
\end{abstract}

Kata kunci : imunomodulator, imunoprotektor, bawang dayak, ekstrak etanol

\begin{abstract}
Determination ability of the onion bulb extract dayak (Eleutherine Palmifolia (L.) Merr) as immunoprotector and immunomodulators to mice $B A L B / c$ by observation number of $C D 56+$ and $C D$ $8+$ expression cells using Immunohistochemistry. Statistical analysis by one-way ANOVA followed by Least Significant Difference test (LSD) showed that the ethanol extract of onion bulbs Dayak showed significantly different results (significant) on CD 8+ cells while CD 56+ expression cells showed no different results (nonsignificant). This means that the ethanol extract of onion bulbs Dayak potentially as an immunomodulator and immunoprotector on cytotoxic cells $(C D 8+)$ for cellular immunity. The ethanol extract onion bulbs Dayak based on the amount the average increase in CD 56+ expression cells, but there is still so low that the test results are not significant.
\end{abstract}

Keywords: immunomodulator, imunoprotektor, onions dayak, ethanol extract 


\section{PENDAHULUAN}

Pemberian kortikosteroid yang juga disebut steroid mengubah sistem kekebalan secara umum. Pengunaan obat ini jangka panjang dapat menekan imun sistem dan gangguan pada tulang (Sumarwoto, 2004). Imunoprotektor dan imunomodulator adalah bahan (obat) yang dapat mempertahankan dan mengembalikan ketidakseimbangan sistem imun (Chairul dan Praptiwi, 2008).Flavonoid berpotensi sebagai imunostimulan karena mampu meningkatkan produksi IL-2 yang terlibat dalam aktivasi dan proliferasi sel $\mathrm{T}$. Flavonoid dapat menginduksi Th1 untuk menghasilkan IFN- $\gamma$. IFN- $\gamma$ juga merupakan mediator poten dalam regulator perkembangan sel Th. Interferon gama (IFN- $\gamma$ ) termasuk keluarga limfokin karena IFN ini dihasilkan oleh limfosit T. Hubungan ini dapat dilihat dengan koefisienkorelasi yang cukup kuat antara IFN- $\gamma$ dengan NK sel dan $\mathrm{CD}^{+}$. Sel NK yang diaktifkan juga merupakan sumber berbagai sitokin yang mengatur sel sistem imun lainnya. Sel NK memberikan pertahanan pertama sampai sistem imun spesifik seperti sel $\mathrm{T}$ $\mathrm{CD}^{+}$dan antibodi dapat bekerja. Sel NK dapat memproduksi IFN-gamma dan TNF-alfa yang merupakan sitokin imunoregulator poten. Meningkatnya produksi IFN- $\gamma$ meningkatkan komponen immune surveillance yaitu aktivitas sel NK yang berfungsi sebagai pertahanan lini terdepan, juga peningkatan fungsi sel $T$ sitotoksis $\left(\mathrm{CD} 8^{+}\right)$. Senyawa bioaktif pada beberapa ekstrak herba diantaranya Flavonoid dapat meningkatkan proliferasi sel limfosit atau sel $\mathrm{T}$, sehingga bawang dayak dapat digunakan sebagai imunomodulator (Dewi et al, 2013). Masyarakat Dayak di Kalimantan Tengah menggunakan tanaman bawang dayak untuk meningkatkan daya tahan tubuh. Tanaman obat ini dapat digunakan sebagai bahan yang bersifat modulasi imun sistem, tetapi proses pencegahan penurunan imun sistem dari tanaman bawang dayak terhadap modulasi imun sistem masih belum dapat dijelaskan ( Abdullah, 2015). Berdasarkan itu peneliti berupaya untuk melakukan penelitian berkaitan antara tanaman bawang dayak dengan modulasi imun sistem.

\section{METODE PENELITIAN}

\section{Instrumen Penelitian}

1. Alat pemeliharaan mencit : Kandang mencit dari kotak plastik, ram kawat, alas kandang, tempat makanan dan botol air.

2. Alat untuk pembedahan mencit : kotak kaca dan penutup kaca pembiusan, scalpel (pisau bedah), surgical scissor (gunting bedah) dan pinset.

3. Alat untuk melarutkan dan pemberian ekstrak etanol umbi bawang dayak : timbangan mikro Toledo, tabung falcon, alumunium foil, vortex mixer, sonde lambung, spuit $1 \mathrm{ml}$ terumo dan rak tabung reaksi.

4. Mikroskop.

\section{Bahan Penelitian}

1. Hewan coba dengan kriteria jenis mencit (Mus musculus) : BALB/c berjenis kelamin : jantan, umur 12 minggu dengan berat badan 25 - 30 gram, kesehatan mencit dapat diamati dengan gerakan cukup lincah, tidak lesu, kulit bersih dan tanpa luka, mata terang dan tidak sayu.

2. Jenis makanan pellet $\mathrm{CP} 511$ dan jenis minuman aquadestila.

3. Perawatan mencit pemberian makanan pellet, pemberian minum secara ad libitum $5 \mathrm{ml} / \mathrm{ekor} / 4$ hari,penggantian sekam untuk alas tidur 2 hari sekali, untuk sanitasi kandang dibersihkan setiap hari dengan suhu sesuai dengan suhu ruang, ventilasi dan sinar matahari yang cukup dan tidak lembab.

4. Pembuatan ekstrak etanol bawang dayak.

Umbi bawang dayak dikupas kulit luarnya dicuci bersih dan diiris tipis-tipis, kemudian diangin-anginkan hingga kering. Selanjutnya irisan umbi bawang dayak tersebut dibuat serbuk. Ditimbang 500 gram serbuk umbi bawang dayak kering, ditambahkan $2 \mathrm{ml}$ etanol kemudian disimpan selama 24 jam ( serbuk bawang dayak dilarutkan dalam $2 \mathrm{ml}$ etanol $96 \%$ dengan metode maserasi yaitu bahan direndam etanol 1 x 24 jam hingga etanolnya menguap, lalu disaring untuk diambil fibrat nya). Besoknya ditampung kemudian dirotavator. Ada sisa sari ditambahkan 1,5 liter etanol, didiamkan 24 jam. Ampas bawang dayak dimaserasi 
kembali selama 1 x 24 jam kemudian diambil filtratnya. Besoknya diambil lagi, dirotavator kembali, sisanya diberi etanol 1,5 liter, hal ini dilakukan selama 3 hari berturut-turut. Pembagian filtrat dilakukan 3 kali kemudian semua filtrat dikumpulkan menjadi satu, lalu diuapkan dengan alat rotary evaporator buchi R-200 melalui penurunan tekanan pada suhu $40-45$ derajat celcius, sehingga diperoleh ekstrak kental bawang dayak. Selanjutnya dibuat sediaan ekstrak etanol umbi bawang dayak konsentrasi $50 \mathrm{mg} / \mathrm{kgBB}$ dengan cara diambil 0,1 ml EEUBD larutkan bersama $0,1 \mathrm{ml}$ larutan $\mathrm{CMC} \mathrm{Na}^{+} 0,5 \%$. Dibuat juga sediaan ekstrak etanol umbi bawang dayak konsentrasi $100 \mathrm{mg} / \mathrm{kgBB}$ dengan cara diambil 0,2 $\mathrm{ml}$ EEUBD larutkan bersama $0,1 \mathrm{ml}$ larutan $\mathrm{CMC} \mathrm{Na}^{+} 0,5 \%$. Terakhir dibuat sediaan ekstrak etanol umbi bawang dayak konsentrasi $200 \mathrm{mg} / \mathrm{kgBB}$ dengan cara diambil $0,3 \mathrm{ml}$ EEUBD larutkan bersama $0,1 \mathrm{ml}$ larutan $\mathrm{CMC} \mathrm{Na}^{+} 0,5 \%$.

5. Pembuatan larutan Metilprednisolon berdasarkan dosis oral $25 \mathrm{mg} / \mathrm{kgBB}$

$\begin{array}{llr}\text { Pembuatan } & \text { larutan } & \text { induksi } \\ \text { metilprednisolon } & \text { berupa } & 0,08 \quad \mathrm{mg}\end{array}$ metilprednisolon /30 grBB mencit/ hari dilarutkan bersama $0,2 \mathrm{ml}$ larutan CMC $\mathrm{Na}^{+} 0,5 \%$.

6. Ketamin ( Ketamine $\mathrm{HCl} /$ 2-(0chlorophenil) - 2 (methylamino) cyclohexanone hydrochloride ) dengan dosis $0,025 \mathrm{mg} / 10$ grBB mencit berdasarkan dosis $10 \mathrm{mg} / \mathrm{kgBB}$.

7. Larutan $\mathrm{CMC} \mathrm{Na}{ }^{+} 0,5 \%$

8. Formalin $10 \%$, etanol 70\%, 80\%, 99\%, xylol, Paraffin cair, kaset, cover slip, base mould, beker glass, gelas ukur, termometer, cutter, pinset panjang, tissue processor auto technicon", hot plate, cold plate, paraffin dispenser untuk membuat preparat.

9. Rotary microtome, disposable blad, kuas cat air kecil nomor 1, Tissue flotation bath, kaca obyek, diamond pencil, staining rack, hot plate, aquadestilata.

10.Monoklonal antibodi terhadap NK sel yaitu CD $56^{+}$dan $\mathrm{CD} 8^{+}$(Rat Anti Mouse).

Ekstrak yang diteliti berupa ekstrak etanol dari umbi Bawang Dayak. Jumlah mencit yang digunakan pada penelitian ini adalah 30 ekor dan dibagi secara acak menjadi 5 kelompok, masing-masing kelompok terdiri dari 6 ekor. Kelompok pertama kontrol negatif diberi $\mathrm{CMC} \mathrm{Na}$, kelompok kedua diberi Metilprednisolon, kelompok ketiga, keempat dan kelima diberi ekstrak etanol umbi bawang dayak berturut-turut dengan dosis 50,100 dan $200 \mathrm{mg} / \mathrm{kgBB}$ bersama Metilprednisolon dengan dosis $0,08 \mathrm{mg} / 30$ grBB mencit/hari. Pemberian perlakuan dilakukan 1 kali sehari pada sore hari. Sebelum diberikan perlakuan, semua mencit dalam setiap kelompok pelakuan diaklimatisasi selama 1 minggu. Proses perlakuan berlangsung selama 14 hari dan pada pagi hari ke 15 dilakukan terminasi untuk pengambilan sampel KGB mencit. Pengamatan jumlah sel pengekspresi CD $56^{+}$dan $\mathrm{CD}^{+}$dengan menggunakan metode Imunohistokimia. Analisis statistik dengan Anova satu arah dilanjutkan dengan uji Beda Nyata Terkecil (BNT).

\section{HASIL DAN PEMBAHASAN}

\section{Pengaruh Pemberian Ekstrak Etanol Umbi Bawang Dayak (EEUBD) Terhadap Pencegahan Penurunan Jumlah NK sel (CD $\mathbf{5 6}^{+}$)}

Sel yang mengekspresikan CD $56^{+}$ akan berwarna kecoklatan dengan perbesaran $400 \mathrm{x}$ pada 10 lapang pandang.

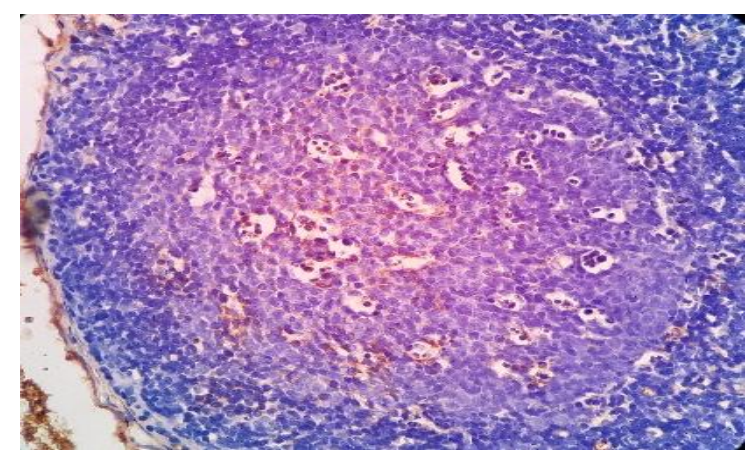

Gambar 5.1.2

Mikroskopi sel penghasil CD $56^{+}$pada KGB mencit kelompok K1. Tampak sel yang menghasilkan $\mathrm{CD} 56^{+}$berwarna cokelat. Perbesaran 400 kali, pewarnaan IHC. 


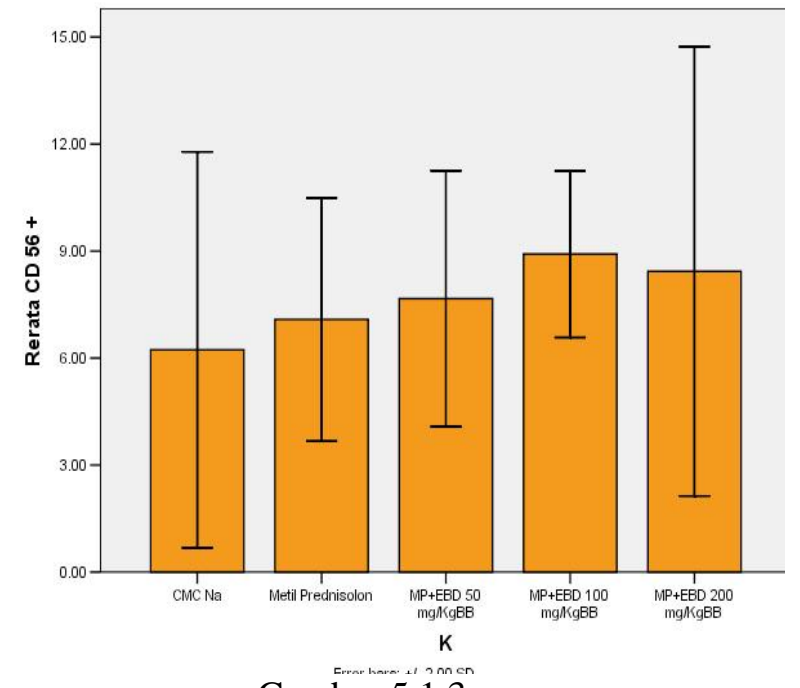

Gambar 5.1.3

Rerata jumlah sel pengekspresi CD $56^{+}$pada setiap Kelompok Perlakuan

Tabel 5.1.2 Perbedaan jumlah sel pengekspresi CD $56^{+}$antar kelompok perlakuan

ANOVA; $F=1,358 ;$ harga $p=0,277$

\section{Pengaruh Pemberian Ekstrak Etanol Umbi}

Bawang Dayak (EEUBD) Terhadap Pencegahan Penurunan Jumlah Sel Pengekspresi CD 8

Sel yang mengekspresikan $\mathrm{CD} \quad 8^{+}$akan berwarna kecoklatan dengan perbesaran $400 \mathrm{x}$ pada 10 lapang pandang.

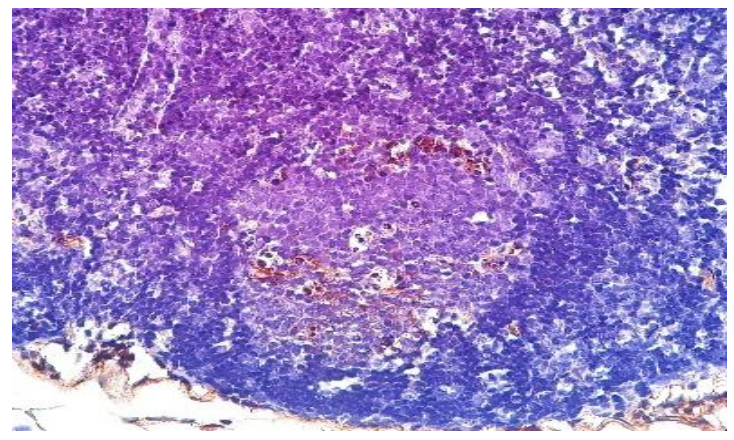

Gambar 5.2.2

Mikroskopi sel penghasil CD $8^{+}$pada KGB mencit kelompok K1. Tampak sel yang menghasilkan $\mathrm{CD} 8^{+}$berwarna cokelat. Perbesaran 400 kali, pewarnaan IHC.

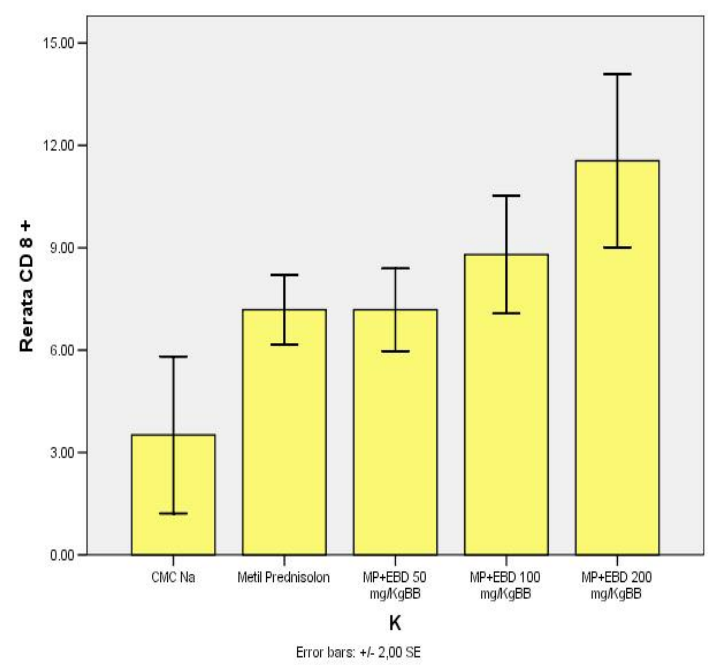

Gambar 5.2.3

Rerata jumlah sel pengekspresi CD $8^{+}$pada

\begin{tabular}{|c|c|c|c|c|}
\hline Kelompok & Rerata & SD & Minimum & Maksimum \\
\hline $\mathrm{K} 1 \mathrm{CMC} \mathrm{Na}$ & $3,52^{\mathrm{a}}$ & 2,82 & 1,00 & 7,90 \\
\hline $\begin{array}{l}\text { K2 } \\
\text { Metiprednisolon } \\
\text { (MP) }\end{array}$ & $7,18^{b}$ & 1,24 & 5,50 & 8,30 \\
\hline $\begin{array}{l}\mathrm{K} 3 \mathrm{MP}+ \\
\mathrm{EEUBD} 50 \\
\mathrm{mg} / \mathrm{KgBB}\end{array}$ & $7,18^{\mathrm{b}}$ & 1,48 & 5,50 & 9,30 \\
\hline $\begin{array}{l}\mathrm{K} 4 \mathrm{MP}+ \\
\mathrm{EEUBD} 100 \\
\mathrm{mg} / \mathrm{KgBB}\end{array}$ & $8,80^{\mathrm{b}}$ & 2,12 & 5,80 & 11,70 \\
\hline $\begin{array}{l}\mathrm{K} 5 \mathrm{MP}+ \\
\mathrm{EEUBD} 200 \\
\mathrm{mg} / \mathrm{KgBB}\end{array}$ & $11,55^{\mathrm{c}}$ & 3,11 & 7,40 & 14,90 \\
\hline
\end{tabular}

setiap Kelompok Perlakuan 
Tabel 5.2.2 Perbedaan jumlah sel pengekspresi CD $8^{+}$antar kelompok perlakuan

ANOVA; F=9,890; harga $p<0,0001$

\begin{tabular}{lcccc}
\hline Kelompok & Rerata & SD & Minimum & Maksimum \\
\hline K1 CMC Na & 6,23 & 2,77 & 2,10 & 9,40 \\
K2 & 7,08 & 1,71 & 4,90 & 9,40 \\
$\begin{array}{l}\text { Metiprednisolon } \\
\text { (MP) }\end{array}$ & & & & \\
K3 MP + & 7,67 & 1,79 & 5,90 & 10,90 \\
$\begin{array}{l}\text { EEUBD 50 } \\
\text { mg/KgBB }\end{array}$ & & & & \\
K4 MP + & 8,92 & 1,17 & 7,70 & 10,60 \\
$\begin{array}{l}\text { EEUBD 100 } \\
\text { mg/KgBB }\end{array}$ & & & & \\
K5 MP + & 8,43 & 3,15 & 6,10 & 14,60 \\
$\begin{array}{l}\text { EEUBD 200 } \\
\text { mg/KgBB }\end{array}$ & & & & \\
\hline
\end{tabular}

Catatan: perbedaan huruf superscript pada rerata menunjukkan adanya perbedaan bermakna dengan menggunakan uji komparasai ganda Least Significant Difference (harga $\mathrm{p}<0,05)$

Imunodefisiensi merupakan defek pada salah satu atau lebih komponen imunitas tubuh yang dapat meninmbulkan gejala klinis, bahkan sampai mengancam nyawa. Terdapat beberapa karakteristik utama imunodefisiensi, yaitu memiliki hasil akhir berupa peningkatan suspektibilitas terhadap infeksi, peningkatan suspektibilitas terhadap kanker, peningkatan insidens autoimunitas, dan disebabkan oleh defek maturasi/aktivasi limfosit (Kumar et al, 2010).

Imunodefisiensi dapat dibagi menjadi kelainan imunodefisiensi primer, yang hampir selalu ditentukan oleh faktor genetik, dan imunodefisiensi sekunder, yang dapat muncul sebagai komplikasi dai kanker, infeksi, malnutrisi, atau efek samping imunosupresan, radiasi, atau kemoterapi. Sebagian besar penyakit imunodefisiensi primer ditentukan secara genetik dan mempengaruhi bagian humoral dan/atau seluler dari imunitas adaptif (dimediasi oleh sel limfosit $\mathrm{B}$ dan $\mathrm{T}$ ), atau dapat juga mempengaruhi mekanisme defensif dari imunitas bawaan (sel NK, fagosit, atau komplemen). Defek pada imunitas adaptif umumnya disubklasifikasikan pada komponen yang terutama terkait (sel B/T/keduanya). Imunodefisensi sekunder dapat dijumpai pada individu dengan berbagai kondisi. Penyebab yang paling sering adalah virus HIV. Secara umum, imunodefisiensi sekunder disebabkan oleh dua mekanisme utama, yaitu imunosupresi yang muncul akibat komplikasi dari penyakit atau keadaan lain, dan imunodefisiensi iatrogenik yang muncul sebagai efek samping dari suatu terapi atau perlakuan lain (Abbas dan Lichtman, 20012).

Beberapa obat diberikan untuk
menyupresi respon imun, seperti kortikosteroid dan siklosporin. Selain itu, kemoterapi pada penderita kanker juga memliki efek samping imunosupresi berupa efek sitotoksik pada limfositselama beberapa saat, sehingga pasien kanker yang baru menjalani kemoterapi akan mengalami satu periode dimana dia akan lebih mudah terinfeksi suatu mikroorganisme (Kumar et al, 2010).

Meningkatkan sistem imun bisa dilakukan dengan pemberian suatu senyawa yang dapat memodulasi sistem imun (imunomodulator). Senyawa yang mempunyai bioaktifitas sebagai agen imunostimulan adalah golongan senyawa polisakarida, terpenoids, alkaloid dan polifenol (Wagner, 1985). Senyawa bioaktif pada beberapa ekstrak herba diantaranya Flavonoid berpotensi sebagai imunostimulan karena mampu meningkatkan produksi IL-2 yang terlibat dalam aktivasi dan proliferasi sel limfosit atau sel T (Dewi et al, 2013). Bahan ini terkandung dalam salah satu tanaman berkhasiat obat dari Kalimantan Tengah yaitu tanaman bawang dayak (Yusni, 2008; Muliatie, 2013). Sehingga pada penelitian ini digunakan tumbuhan Bawang Dayak (Eleutherine palmifolia Merr.) sebagai bahan uji untuk membuktikan efek terhadap peningkatan sistem imun seluler pada mencit model imunodefisiensi khususnya pencegahan penurunan jumlah NK Sel (CD $56^{+}$) dan $\mathrm{CD} 8^{+}$.

Pada penelitian ini menggunakan sampel mencit strain BALB/c sebagai model 
imunosupresi dengan pemberian obat kortikosteroid (Metilprednisolon). Penggunaan Metilprednisolon pada penelitian ini dengan alasan pertimbangan obat tersebut banyak digunakan dan merupakan kortikosteroid oral yang paling sering digunakan dalam terapi supresi penyakit jangka panjang (PIO Nas, 2015).

Kelompok I merupakan perlakuan kontrol tanpa perlakuan ekstrak etanol umbi bawang dayak dan tanpa diinduksi metilprednisolon hanya diberi $\mathrm{CMC} \mathrm{Na}^{+} 0,5$ $\%$. Kelompok II merupakan kontrol positif yaitu kelompok perlakuan yang diinduksi kortikosteroid jenis metilprednisolon 0,08 $\mathrm{mg} / 30 \mathrm{grBB}$ mencit/ hari terlarut dlm $0,2 \mathrm{ml}$ aquades tanpa perlakuan ekstrak etanol umbi bawang dayak. Sedangkan kelompok III-V dengan perlakuan ekstrak etanol umbi bawang dayak dengan dosis $0,25 \mathrm{ml} / 30 \mathrm{~g}$ berat badan mencit konsentrasi $50 \mathrm{mg} / \mathrm{kgBB}, \quad 100$ $\mathrm{mg} / \mathrm{kgBB}$ dan $200 \mathrm{mg} / \mathrm{kgBB}$, diberikan sekali sehari selama 14 hari bersamaan pemberian induksi metilprednisolon pada sore hari secara per-oral (sonde intragastrik)

\subsection{Pengaruh Pemberian Ekstrak Etanol Umbi Bawang Dayak (EEUBD) Terhadap Pencegahan Penurunan Jumlah NK Sel}

Hasil penelitian yang tampak pada Gambar 5.1.3 menunjukkan bahwa pemberian Ekstrak Etanol Umbi Bawang Dayak (EEUBD) dosis $0,25 \mathrm{ml} / 30 \quad \mathrm{~g}$ dengan konsentrasi $50 \mathrm{mg} / \mathrm{kgBB}, 100 \mathrm{mg} / \mathrm{kgBB}$ dan $200 \mathrm{mg} / \mathrm{kgBB}$ bersama Metilprednisolon dengan dosis $0,08 \mathrm{mg} / 30 \mathrm{grBB}$ mencit/ hari yang diberikan sekali sehari selama 14 hari, mampu mempertahankan jumlah sel pengekspresi CD $56^{+}$pada semua kelompok mencit yang diinduksi EEUBD (Tabel 5.1) dibandingkan dengan kontrol negatif (K1/CMC Na) dan K2 (Metilprednisolon) yaitu pemberian induksi metilprednisolon dengan dosis $0,08 \mathrm{mg} / 30 \mathrm{grBB}$ mencit/ hari. Pada induksi metilprednisolon (K2) terjadi peningkatan jumlah sel pengekspresi CD $56^{+}$ dibandingkan dengan kontrol negatif (K1), tapi pemberian EEUBD bersama metilprednisolon (K3-K4-K5) meski terjadi peningkatan dibandingkan $\mathrm{K} 1$ dan $\mathrm{K} 2$ namun tidak banyak sehingga dianggap mampu mempertahankan atau mencegah penurunan jumlah sel pengekspresi CD $56^{+}$meski pada K4 terjadi sedikit peningkatan. Ini ditunjukkan dari grafik rerata jumlah tertinggi sel pengekspresi CD $56^{+}$pada setiap kelompok perlakuan, dimana semakin tinggi dosis EEUBD (K5) yang diinduksikan mampu mempertahankan jumlah $\mathrm{CD} 56^{+}$tidak jauh melebihi jumlah kelompok K1.

Pada penggunaan metilprednisolon (steroid) dalam kurun waktu lama dapat menyebabkan gangguan sistem kekebalan tubuh (penurunan imunitas) dan penghentian penggunaan steroid akan berdampak buruk jika tanpa tapering off. Rangsangan steroid dapat mengganggu sistem kekebalan tubuh dan dampak buruk yang ditimbulkannya kemudian menstimulasi sel $\mathrm{T}$ dari kelenjar getah bening (KGB) menghasilkan interferon$\gamma(\mathrm{INF}-\gamma)$ yang mengaktivasi NK sel dan CD $8^{+}$(Campbell dalam Sulistiyana, 2015). NK sel dan $\mathrm{CD} 8^{+}$berfungsi membunuh sel-sel yang terinfeksi dan tidak diinginkan oleh tubuh (Abbas dan Lichtman, 2012).

Berdasarkan hasil jumlah rerata (Gambar 5.1.3) menunjukkan bahwa induksi EEUBD dosis $50 \mathrm{mg} / \mathrm{kgBB}, 100 \mathrm{mg} / \mathrm{kgBB}$ dan $200 \mathrm{mg} / \mathrm{kgBB}$ bersama metilprednisolon pada mencit selama 14 hari secara oral mampu meningkatkan jumlah sel pengekspresi CD $56^{+}$ dibandingkan kelompok perlakuan K1 dan K2. Didapatkan adanya lonjakan peningkatan jumlah sel pengekspresi CD $56^{+}$pada $\mathrm{K} 4$ yaitu pemberian induksi EEUBD $100 \mathrm{mg} / \mathrm{kgBB}$ bersama metilprednisolon pada mencit selama 14 hari secara oral. Peningkatan jumlah sel pengekspresi $\mathrm{CD} 56^{+}$dengan penambahan EEUBD mampu mengurangi dampak gangguan imunitas akibat Metilprednisolon sehingga mampu berperan dalam imunitas seluler.

Hasil tersebut di atas ternyata berdasarkan uji statistik tidak bermakna (signifikan) dengan nilai $\mathrm{p}>0,05$ meski pada Gambar 5.1.3 jumlah rerata menunjukkan peningkatan jumlah rerata sel pengekspresi $\mathrm{CD} 56^{+}$untuk $\mathrm{K} 3, \mathrm{~K} 4$ dan $\mathrm{K} 5$ dibandingkan K1 dan K2. Pada tabel 5.1.1 uji normalitas ada peningkatan sel pengekspresi $\mathrm{CD} 56^{+}$untuk K4 yaitu pemberian induksi EEUBD dosis $100 \mathrm{mg} / \mathrm{kgBB}$ bersama metilprednisolson dengan nilai $\mathrm{p} 0,821$. Meski hasil ini secara statistik tidak menghasilkan perbedaan yang 
bermakna namun dimungkinkan EEUBD dosis $100 \mathrm{mg} / \mathrm{kgBB}$ yang diberikan mampu memenuhi standar karena hasil yang ada menunjukkan peningkatan jumlah sel pengekspresi CD $56^{+}$menyamai hasil kontrol $\mathrm{K} 1$ (nilai $\mathrm{p}$ 0,856) sehingga dianggap mampu mencegah terjadinya penurunan sel $\mathrm{CD} 56^{+}$ dan dapat berperan sebagai imunoprotektor maupun imunomodulator yang dapat memodulasi dan mengontrol produksi Sel NK.

Sel NK berperan penting dalam imunitas nonspesifik pada patogen intraseluler yang memiliki kemampuan mengenal dan membunuh sel abnormal, serta menghancurkan sel yang mengandung virus atau sel neoplasma. Sel NK diaktifkan oleh interferon yang biasanya diproduksi dan dilepaskan oleh sel yang terinfeksi virus itu sendiri.. Interferon mempunyai pengaruh dalam mempercepat pematangan dan efek sitolitik Sel NK. Interferon juga menyebabkan peningkatan daya tahan terhadap virus pada sel-sel yang tidak terinfeksi (Abbas dan Lichtman, 2012).

Penelitian ini dapat menjadi solusi untuk menentukan standar dosis terapi yang nantinya digunakan untuk memodulasi produksi Sel NK pada manusia yang mengalami gangguan sistem imun akibat kortikosteroid dengan mengkonversi hasil yang didapatkan dari penelitian ini sehingga mampu memodulasi dan mengontrol produksi NK sel tetap dalam kondisi normal atau mendekati normal agar sistem imun tetap stabil. Jika terjadi imunodefisiensi berat maka pemberian EEUBD dengan dosis bertahap dapat ditingkatkan sehingga mampu memodulasi dan mengontrol produksi $\mathrm{CD} 56^{+}$ dan diharapkan imunitasnya kembali stabil atau normal.

\subsection{Pengaruh Pemberian Ekstrak Etanol Umbi Bawang Dayak (EEUBD) Terhadap Pencegahan Penurunan Jumlah CD $8^{+}$}

Hasil penelitian ini berdasarkan Gambar 5.2.3 menunjukkan jumlah rerata sel pengekspresi $\mathrm{CD} 8^{+}$meningkat pada setiap perlakuannya dibandingkan dengan $\mathrm{K} 1$ yaitu mencit yang hanya diberikan CMC Na secara oral. Pemberian metilprednisolon pada K2 menyebabkan peningkatkan jumlah sel pengekspresi $\mathrm{CD} 8^{+}$dibandingkan $\mathrm{K} 1$. Pada kelompok perlakuan dengan Ekstrak Etanol Umbi Bawang Dayak (EEUBD) dosis 50 $\mathrm{mg} / \mathrm{kgBB}$ (K3) mampu mempertahankan jumlah sel pengekspresi $\mathrm{CD} 8^{+}$memiliki kisaran yang sama dengan rerata K2 yang hanya diinduksi Metilprednisolon. Kelompok perlakuan K4 dengan Ekstrak Etanol Umbi Bawang Dayak (EEUBD) dosis $100 \mathrm{mg} / \mathrm{kgBB}$ terjadi peningkatan rerata jumlah sel pengekspresi $\mathrm{CD} 8^{+}$dibandingkan dengan kelompok mencit yang tidak diinduksi yaitu hanya diberikan CMC Na secara oral (K1), kelompok mencit yang hanya diinduksi Metilprednisolon (K2). Lonjakan peningkatan tampak pada K5 yaitu kelompok mencit yang diinduksi Ekstrak Etanol Umbi Bawang Dayak (EEUBD) dosis $200 \mathrm{mg} / \mathrm{kgBB}$ bersama Metilprednisolon dengan dosis $0,08 \mathrm{mg} / 30$ grBB mencit/ hari yang diberikan sekali sehari selama 14 hari memiliki jumlah rerata sel pengekspresi $\mathrm{CD} 8^{+}$sangat tinggi sehingga tampak peningkatan bermakna dibandingkan dengan kelompok K1-K4. Hal tersebut secara penghitungan uji statistik menghasilkan nilai $\mathrm{p}<0,05$ yang menunjukan hasil signifikan yaitu berbeda bermakna.

Pada Tabel 5.2.2 menunjukkan jumlah rerata sel pengekspresi CD $8^{+}$pada $\mathrm{K} 2\left(7,18^{\mathrm{b}}\right)$ yang hanya diinduksi Metilprednisolon memiliki jumlah rerata $\mathrm{CD} 8^{+}$yang sama besar dengan kelompok $\mathrm{K} 3\left(7,18^{\mathrm{b}}\right)$ yang diinduksi EEUBD dosis $50 \mathrm{mg} / \mathrm{kgBB}$ bersama Metilprednisolon dengan dosis $0,08 \mathrm{mg} / 30$ grBB mencit/ hari. Hal ini menunjukkan bahwa EEUBD dosis $50 \mathrm{mg} / \mathrm{kgBB}$ mampu mempertahankan jumlah rerata $\mathrm{CD} 8^{+}$, dengan mencegah penurunan maupun peningkatan $C D$ $8^{+}$. Dapat disimpulkan bahwa induksi EEUBD dosis $50 \mathrm{mg} / \mathrm{kgBB}$ bersama Metilprednisolon dengan dosis $0,08 \mathrm{mg} / 30 \mathrm{grBB}$ mencit/ hari selama 14 hari memenuhi standar terapi yang diinginkan.

Peningkatan jumlah rerata $\mathrm{CD} 8^{+}$pada kelompok K4 dan K5 menunjukkan bahwa semakin tinggi dosis EEUBD yang diinduksikan bersama Metilprednisolon mampu mempertahankan jumlah dan meningkatkan $\mathrm{CD} 8^{+}$. Peningkatan yang signifikan dari jumlah rerata $\mathrm{CD} 8^{+}$pada kelompok K5 menghasilkan lonjakan yang sangat jauh dibandingkan $\mathrm{K} 4$, hal ini dimungkinkan dosis yang diberikan yaitu EEUBD dosis $200 \mathrm{mg} / \mathrm{kgBB}$ bersama 
Metilprednisolon tmerupakan dosis terapi yang dapat dipertimbangkan untuk memicu/memodulasi peningkatan sel pengekspresi $\mathrm{CD} 8^{+}$secara cepat pada kondisi status imun yang rendah.

Berdasarkan hasil uji normalitas (Gambar 5.2.1) tampak bahwa induksi EEUBD dosis $50 \mathrm{mg} / \mathrm{kgBB}, 100 \mathrm{mg} / \mathrm{kgBB}$ dan $200 \mathrm{mg} / \mathrm{kgBB}$ bersama metilprednisolon pada mencit selama 14 hari secara oral menunjukkan hasil yang hampir sama pada nilai p yaitu $\mathrm{K} 3(\mathrm{p}=0,924), \mathrm{K} 4(\mathrm{p}=0,964)$ dan K5 $(\mathrm{p}=0,948)$. Hal ini menunjukkan khasiat EEUBD yang mampu mempertahankan peningkatkan jumlah sel pengekspresi $\mathrm{CD} 8^{+}$ dalam jumlah yang hampir sama (seragam) dibandingkan kelompok perlakuan K1 $(\mathrm{p}=0,878)$ dan $\mathrm{K} 2(\mathrm{p}=0,539)$. Hasil ini secara statistik dianggap memiliki perbedaan yang bermakna dimana EEUBD dosis $50 \mathrm{mg}$ yang diberikan sudah memenuhi standar terapi karena mampu mencegah terjadinya penurunan jumlah sel pengekspresi $\mathrm{CD} 8^{+}$. Pemberian EEUBD dosis $100 \mathrm{mg}$ dan 200 $\mathrm{mg} / \mathrm{kgBB}$ bersama metilprednisolon mampu meningkatkan jumlah sel pengekspresi $\mathrm{CD} 8^{+}$ dibandingkan kelompok K1 dan K2. Peningkatan yang terjadi menunjukkan bahwa pemberian EEUBD dosis 50,100 dan 200 $\mathrm{mg} / \mathrm{kgBB}$ dapat berperan sebagai imunoprotektor dan imunomodulator yang dapat memodulasi dan mengontrol produksi sel sitotoksik $\left(\mathrm{CD} 8^{+}\right)$.

Berdasarkan hasil uji normalitas pada Tabel 5.2.1 Kelompok K2 memiliki nilai $\mathrm{p}=$ 0,539 sangat rendah dibandingkan dengan kelompok perlakuan lainnya. Pada K3 $(\mathrm{p}=0,924), \mathrm{K} 4 \quad(\mathrm{p}=0,964)$ dan $\mathrm{K} 5 \quad(\mathrm{p}=0,948)$ tampak 3 kelompok tersebut memiliki nilai $\mathrm{p}$ yang hampir sama dan tidak jauh dari nilai $p$ yang dimiliki $\mathrm{K} 1(\mathrm{p}=0,878)$ sebagai kelompok kontrol, sehingga jumlah sel pengekspresi CD $8^{+}$dalam kisaran jumlah yang sama dan secara statistik berbeda bermakna bila dibandingkan dengan kelompok perlakuan yang hanya di induksi Metilprednisolon yaitu K2 $(p=0,539)$ dengan hasil uji statistik nilai $\mathrm{p}=0,0001$ $(\mathrm{p}<0,05)$.

Pemberian Metilprednisolon $\left(\mathrm{K} 2=7,18^{\mathrm{b}}\right)$ selama 14 hari diperoleh jumlah rerata $\mathrm{CD} 8^{+}$lebih tinggi dibandingkan kelompok yang hanya diberikan $\mathrm{CMC} \mathrm{Na}$ peroral $\left(\mathrm{K} 1=3,52^{\mathrm{a}}\right)$. Pemberian EEUBD dosis
$50 \mathrm{mg} / \mathrm{kgBB}$ (K3) selama 14 hari diperoleh rerata jumlah $\mathrm{CD} 8^{+}$tidak lebih tinggi dibandingkan K2. Secara statistik hasil ini berbeda bermakna dengan nilai $\mathrm{p}=0,0001$. Selanjutnya pemberian EEUBD dosis 100 $\mathrm{mg} / \mathrm{kgBB}$ (K4) dan dosis $200 \mathrm{mg} / \mathrm{kgBB}$ (K5) diperoleh rerata jumlah $\mathrm{CD} 8^{+}$lebih tinggi daripada kelompok K3 $\left(7,18^{\text {b }}\right)$ namun secara statistik hasil berbeda bermakna dengan nilai $\mathrm{p}$ $(\mathrm{K} 4)=0,000$ dan $\mathrm{p}(\mathrm{K} 5)=0,000(\mathrm{p}<0,05)$. Hal ini menunjukkan bahwa pemberian EEUBD dosis $50 \mathrm{mg} / \mathrm{kgBB}, 100 \mathrm{mg} / \mathrm{kgBB}$ dan dosis $200 \mathrm{mg} / \mathrm{kgBB}$ pada mencit yang diinduksi bersama metilprednisolon pada penelitian ini dapat meningkatkan jumlah CD $8^{+}$secara signifikan. Hal ini kemungkinan karena dosis EEUBD yang diberikanmerupakan dosis yang baik sehingga mampu meningkatkan jumlah $\mathrm{CD} 8^{+}$secara signifikan.

Penggunaan kortikosteroid yang lama mampu menurunkan jumlah limfosit $\mathrm{T}$ sitolitik (CD8+), sehingga rasio limfosit $\mathrm{T}$ sitolitik (CD $8+$ ) terhadap limfosit $\mathrm{T}$ helper (CD4+) menurun dengan akibat kepekaan terhadap infeksi virus, bakteri, dan jamur meningkat. Terjadi kegagalan fungsi dari aktivitas supresi CD8+ sel T suppressor dan sel NK terhadap aktivitas sel T. Hal ini menimbulkan imunodefisiensi sehingga tubuh tidak mampu mengontrol imunitas dan menjadi salah satu faktor yang menyebabkan penyakit berlangsung terus (Hinrichs CS et al, 2010).

Flavonoid merupakan salah satu zat aktif yang terkandung dalam beberapa tanaman herbal. Salah satu tanaman tersebut adalah Bawang Dayak (Eleutherine palmifolia Merr.). Penelitian Abdullah (2015) menemukan bahwa senyawa flavonoid pada ekstrak Bawang Dayak dapat menstimulasi sistem imun, antiviral, antikanker, mengurangi resiko penyakit kardiovaskuler, anti inflamasi dan penangkal radikal bebas. Stimulasi sistem imun ini dilakukan dengan cara meningkatkan aktivitas limfosit $\mathrm{T}$ yang berakibat pada meningkatnya produksi $\mathrm{NK}$ sel dan $\mathrm{CD} 8^{+}$. Dengan demikian kandungan flavonoid dalam Bawang Dayak nampaknya juga berpengaruh terhadap peningkatan jumlah NK sel dan CD $8^{+}$.

Pada penelitian ini menggunakan Ekstrak Etanol Umbi Bawang Dayak (EEUBD) sebagai bahan uji, dimana secara 
empiris mampu merangsang peningkatan daya tahan tubuh. Pemberian EEUBD dosis 50 $\mathrm{mg}, 100 \mathrm{mg}$ dan $200 \mathrm{mg} / \mathrm{kgBB}$ bersama metilprednisolon pada mencit selama 14 hari ternyata mencapai rerata jumlah $\mathrm{CD} 8^{+}$jauh lebih tinggi dari pada rerata jumlah $\mathrm{CD} 8^{+}$ pada kelompok K1 dan K2. Hal ini menunjukkan bahwa pemberian EEUBD dosis $50 \mathrm{mg} / \mathrm{kgBB}$ dapat berperan sebagai imunoprotektor dan imunomodulator yang dapat memodulasi dan mengontrol produksi CD $8^{+}$. Sedangkan pemberian EEUBD dosis $100 \mathrm{mg}$ dan $200 \mathrm{mg} / \mathrm{kgBB}$ dapat berperan sebagai imunoprotektor dan imunomodulator yang dapat memodulasi sekaligus mengontrol produksi CD $8^{+}$.

Hal ini menjadi solusi jika terjadi imunodefisiensi berat maka pemberian EEUBD dengan dosis bertahap dapat ditingkatkan sehingga mampu memodulasi dan mengontrol produksi $\mathrm{CD} 8^{+}$dan diharapkan imunitasnya kembali stabil atau normal.

\section{DAFTAR PUSTAKA}

Abbas AK, Lichtman AH, Pillai S. Cellular and Molecular Immunology. $7^{\text {th }}$ Ed. 2012. Philadelphia : Elsevier. Pg.445-58

Abdullah. 2015. Bawang Dayak untuk Penyembuhan AUTIS dan Zat Fitokimia pada Bawang Dayak. http://www.trubus-online.co.id.

Jakarta 2015. Diakses pada tanggal 3 Maret 2015.

Anonim. 2008. Tanaman Obat Tradisional Bawang Dayak (Eleutherine americana Merr.).

http://kalteng.litbang.deptan. go. id/ Berita. htm. Palangkaraya, 2008. Diakses pada tanggal 31 Oktober 2.

Arung E T, Kusuma I W et al / Nat Med (Tokyo). 2009. Evaluation of medicinal plants from Central Kalimantan for antimelanogenesis 12009 Oct;63(4):473-80. Epub 2009 Jul 18.
Azis, Abdul Latief 2006. Penggunaan Kortikosteroid Di Klinik (The Use of Corticosteroid In Clinics). http://old.pediatrik.com/buletin/2 0060220-uk51j3-buletin.pdf. Jakarta 2006.

Baratawidjaja, Karnen Garna, 2010. Imunologi Dasar. Edisi Kedelapan. Jakarta: Universitas Indonesia

Budiarto E, 2001. Biostatistika untuk Kedokteran dan Kesehatan Masyarakat. EGC: Jakarta

Chairul, Praptiwi, 2008. Uji Efektivitas Imunomodulator Tiga Jenis Zingiberaceae Secara In-Vitro Melalui Pengukuran Aktivitas Sel Makrofag Dan Kapasitas Fagositosis. Jakarta: Puslit Biologi LIPI, 1-7

Corallini F, Secchiero P, Beltrami AP, Cesselli D, Puppato E, Ferrari R, Beltrami CA, Zauli G. 2010. TNF-alpha modulates the migratory response of mesenchymal stem cells to TRAIL. Department of Morphology and Embryology, University of Ferrara;. Diakses 2010-07-29.

Dewi L.K, Widyarti S, Rifai M, 2013. Pengaruh Pemberian Ekstrak Etanol Daun Sirsak (Annona muricata Linn.) terhadap Peningkatan Jumlah Sel T CD4+ dan CD8+ pada Timus Mencit (Mus musculus). Jurnal Biologi. Malang: Universitas Brawijaya, $1-5$

Diperta Tan. Pangan \& Hortikultura Prov. Kalimantan Barat. 2009. Bawang Dayak (Eleutherina Americana). Kalimantan Barat. Diakses pada tanggal 13 Agustus 2009. 
Febrinda A E, Astawan M, Wresdiyati T, and $\begin{array}{llll}\text { Yuliana } & N & \text { D. } & 2013 .\end{array}$ http://Kapasitas antioksidan dan inhibitor alfa glukosidase.blogspot.com/2013/4/ ekstrak umbi bawang dayak html. Diakses pada April 2013.

Grammatikos AP (2008). "The genetic and environmental basis of atopic diseases". Annals of Medicine $\mathbf{4 0}$ (7): 482-95. doi: $10.1080 / 07853890802082096$ . PMID 18608118.

Hinrichs CS, Palmer DC, Rosenberg SA, Restifo NP. 2010. Glucocorticoids do not inhibit antitumor activity of activated CD8+ $\mathrm{T}$ cells. National Cancer Institute (NCI), National Institutes of Health (NIH). Diakses 2010-08-05.

Hemmer C J, Lehr H A, Westphal K, Unverricht M, Kratzius M, and Reisinger E C. 2005. Infection and Immunity, p 1764-1770.

Janeway, Charles; Paul Travers; Mark Walport; Mark Shlomchik (2001). Immunobiology; Fifth Edition. New York and London: Garland Science. pp. e-book. ISBN 978-08153-4101-7.

Kumar V, Abbas AK, Fausto N, Aster JC. Robbins and Cotran pathologic basis of disease. 8th Ed. 2010. Philadelphia : Elsevier. Pg.230-5

Madigan MT, Martinko JM, Dunlap PV, Clark DP. 2008. Biology of Microorganisms 12th edition. San Francisco: Pearson.

Mata Kuliah Biologi, 2012. Respon Imun. Mata kuliah biologi. blogspot.com/2012/06/respon- imun.html. Jakarta 2015. Diakses pada tanggal 24 Juni 2012.

PIO Nas, 2015. Glukokortikoid. pionas.pom.go.id/book/63kortikos teroid/ glukokortikoid. Jakarta 2015.

Ponnusamy Y, Chear N J Y, Ramanathan S, Murugaiyah V, and Lai C S. 2013. Antioxidant and antibacterial properties of Malaysian ferns used traditionally againts infection. J. Nat. Prod. Plant Resour. 3(6): 14-18.

Prescott LM, Harley JP, Klein DA. 2002. Microbiology. 5th Ed. Boston: McGraw-Hill.

Rhen T., Cidlowski J.A.,2005, Antiinflammatory Action of Glucocorticoids _ N New Mechanisms for Old Drugs, Mechanisms of Disease, Vol.353 : 1711-1723

Sudiana IK, 2005. Teknologi Ilmu Jaringan dan Imunohistokimia. Jakarta: Sagung Seto, 1-46

Sudjarwo S A. 2005. The Potency of Piperine as Antiinflamatory and Analgesic in Rats and Mice. Folia Medica Indonesiana, vol.41, no.3.

Sumarwoto T, 2004. Efek Pemberian Ekstrak Kedelai Dalam Menghambat Penurunan Kepadatan Tulang Pada Terapi Kortikosteroid Jangka Panjang Tikus Putih Jantan (Rattus norvegicus). Tesis, Universitas Airlangga, Surabaya.

Sulistyana, M I, 2015. Pemanfaatan Polisakarida Krestin Dari Coriolus versicolor Sebagai Imunomodulator Pada Mus musculus Yang Terpapar 
Mycobacterium tuberculosis

Berdasarkan Indikator

Konsentrasi IL-4 Dan Histologi

Limpa. Skripsi, Universitas

Airlangga, Surabaya.

Veldkamp JF, 2007. Flora Malesiana Buletin.

National Herbarium Netherland

Universiteit Leiden branch The

Netherlands, 54-55.

Wagner H, 1985. Immunostimulants from medicinal plants. In Advances in Chinese medicinal materials research (Eds.) H.M. Chang; H.W. Yeung; W.W. Tso and A. Koo. World Scientific Publ. Co. Singapura : $159-170$.

Warta Penelitian dan Pengembangan Tanaman Industri, Volume 15 Nomor 3, Desember 2009.

Yusni MA, 2008. Perbedaan pengaruh pemberian fraksi etanolik bawang dayak (Eleutherine Palmifolia L. Merr) dengan 5-Fluorouracil terhadap penghambatan pertumbuhan galur sel karsinoma kolon HT29 dan Ekspresi p53 Mutan. Tesis. Universitas Sebelas Maret. Indonesia 